\title{
AZ ÉN SÁTRAM AZ ÉN VÁRAM - A VADKEMPINGEZÉS VÁLTOZÁSA A TISZA-TÓ TÉRSÉGÉBEN
}

\author{
Czicze Gábor - Benkhard Borbála
}

\section{Összefoglalás}

A XX. század második felében megszületett nagy kiterjedésü viztározó, a Tisza-tó ma már kiemelt turisztikai fejlesztési térség része. Vonzerejét a természetközeli táj sokszinüsége jelenti, amely a horgászok számára is változatos lehetöségeket biztosit. Az egész évben horgászható tónál folyamatos fejlesztés alatt áll a horgászturisztikai infrastruktuira és a halállomány gyarapitása. A horgászido" legteljesebb kihasználása, a horgászhelyekhez való ragaszkodás, etetöhelyek védelme, valamint a spórolás a horgászokat a vizparton történö éjszakázásra készteti, azonban a területen a vadkempingezés jogszabályba ütközö. A Debreceni Egyetem Tájvédelmi és Környezetföldrajzi Tanszékén 2001-ben egy diplomamunka keretében elkészült egy vadkempingfelmérés, azonban a terület kezelöi szerint a szemeteléssel együtt ez jelenleg is az egyik legnagyobb probléma a tározó partján. Ezért célul tüztük ki, hogy szakdolgozati kutatás keretében a felmérést megismételjük, illetve kibövitjük. 2019 nyarán elvégeztük a teljes Tisza-tó feltérképezését, vizen és szárazföldön. Ennek során minden helyszinen adatlap kitöltésére és fotódokumentációra került sor. Az illegális sátrazással érintett terület nagyságát, az ott található felépitmények, tüzrakóhelyek, mellékhelységek jellegét, valamint a hulladék mennyiségét egyaránt rögzitettük az adatbázisban, a pontok földrajzi koordinátáival együtt. $A z$ adatok feldolgozásával egyrészt feltárjuk a jelenlegi helyzetet, lehetövé tesszük az egyes öblözetek összehasonlitását, és elemezzük a vadkempingezéssel érintett pontok legális infrastruktúrához való viszonyát. Másrészt a korábban készült felmérés térképeivel összevetve az elmúlt mintegy 20 év változásai is kimutathatóak lesznek. Jelen publikációban ennek a kutatásnak néhány eredményéröl számolunk be. Az eredmények alapján elmondható, hogy összességében csökkent az illegális kempingezés és szemetelés. Azonban a megfelelo" viselkedést elösegitö infrastruktuális fejlesztések és menedzsmentintézkedések ellenére a vártnál jóval kisebb mértékben.

Kulcsszavak: horgászturizmus, vadkempingtérkép, illegális sátorozás, szemetelés JEL: $Z 320$ 


\title{
MY TENT IS MY FORTRESS - CHANGE IN WILDERNESS CAMP IN THE AREA OF TISZA-TÓ
}

\begin{abstract}
The large reservoir of Tisza-tó (sometimes-called Tisza Lake) was born in the second half of 20th century and today defined as individual priority tourism development area. The diverse nature-like landscape is the main attraction, offering a variety of opportunities for sport fishing activities too. The reservoir can be fished by different methods throughout the year, and facilities and fish populations are constantly being developed. Due to the sport fishing habits the anglers use to spend all the nights or longer period at the water, although camp activity is prohibited almost on the whole area.

In 2001, a wilderness camp survey was carried out as part of a thesis at the University of Debrecen, but according to the operators of the area, littering is still one of the biggest problems on the banks of the reservoir. We have therefore set a goal to repeat and expand the survey in the context of thesis research.

In the summer of 2019, we completed the mapping of the entire Tisza-tó reservoir, on water and land. In doing so, a field form and photo documentation was completed at each location. The geographic coordinates, the area affected by illegal camping, type of the constructions, fire pits, the rests and amounts of waste were recorded in to our database about the whole area. By processing the data, we will explore the current situation, allow comparison of each pool and analyse the relationship between the points involved in wildlife camping with legal infrastructure. On the other hand, compared to the maps of the previous survey can be followed the changes in the last 20 years.

In this paper, we present several results of this research. Based on it, illegal camping and littering have decreased overall. However, despite infrastructural improvements and management measures to promote good behaviour, much less than expected.
\end{abstract}

Keywords: fishing tourism, sport fishing activities, mapping of illegal campsites, littering

JEL: $Z 320$ 


\section{Szakirodalmi előzmények}

\section{A Tisza-tó mint horgászparadicsom}

A Tisza hullámterében a Kiskörei vízlépcső 1973 -as üzembehelyezése után, több szakaszban létrejött egy $127 \mathrm{~km}^{2}$ felületű víztest. Az elsődlegesen vízgazdálkodási (öntözési, aszálykár-csökkentési) céllal, valamint energiatermelés érdekében kialakított mesterséges tározó turisztikai jelentőségét jól mutatja, hogy már 1969-ben megalakult a Közép-Tisza-vidéki Üdülőterületi Előkészítő Bizottság (Mészáros, 1974).

A sekély víztározón a duzzasztás, de még inkább az árasztás révén a korábbitól ugyan eltérő, de annál sok tekintetben változatosabb élőhelykomplex jött létre (Halasi-Kovács-Harka, 2000). A természeti értékek jelentőségének köszönhetően a tározótér egy része (Tiszavalki-medence és a Poroszlói-medence) a Hortobágyi Nemzeti Park része, emellett Natura 2000 és Ramsari-területek is (I1.).

A tájképi, hidrológiai és ökológiai mozaikosság a tavat különösen vonzó célponttá teszi a horgászok számára. A Tisza-tóból 51 halfajt mutattak ki (Harka, 1985), ami jóval meghaladja a hasonló méretű állóvizekre jellemző fajszámot. Mindezek eredményeképp mára a horgászturizmust a Tisza-tónál nagy piaci részesedés jellemzi (Benkhard et al., 2013), sőt a tó egyik legmeghatározóbb márkaeleme lett.

A térben és időben változatos adottságú Tisza-tavon az alkalmazható horgászmódszerek is változatosak, ennek következtében a horgászok $80 \%$-a rendszeres viszszajáró (Dávid et al., 2010; Benkhard et al., 2013). A horgászturisták további jellemzői közül csak a kutatásunkhoz kapcsolódókról ejtünk szót röviden.

Korábbi kutatások, valamint a jelen felmérés eredményei alapján is elmondható, hogy a Tisza-tó horgászai szálláshelyet kis arányban vesznek igénybe, illetve keveset költenek rá:

- A KSH adatai $(2013,2018)$ alapján a költési szerkezetben a belföldi több napos utazások során a szálláshely 35-50\%-ot tesz ki, míg a Tisza-tó horgászai körében végzett felmérés során ez csak 7\% volt (Benkhard et al., 2013).

- A horgászok több, mint harmada (38,7\% illetve 46,7\%) egyáltalán nem vett igénybe szálláshelyet (Dávid et al., 2010; Benkhard et al., 2013).

A fenti eredményeknek az is az oka, hogy a Tisza-tónál sok a közeli településeken élő, vagy ott nyaralóingatlannal rendelkező horgász. Azonban a vízparton történő éjszakázás sok horgász számára szinte magától értetődő, a partról történő horgászat sajátosságai miatt:

- megszokott, kedvelt beállóhelyekhez való ragaszkodás,

- etetőhelyek védelme,

- a horgászidő legteljesebb kihasználása,

- parton töltött éjszakák az esti, hajnali kapás reményében,

- spórolás. 


\section{A tisza-tavi horgászat jogszabályi háttere}

A horgászat káros hatásainak megelőzésére, illetve csökkentésére az általános, országos érvényü jogszabályokon túl a helyi horgászrend kialakításával is törekszik a mindenkori hasznosító. A fentebb kiemelt két problémakörre (vadkempingezés és szemetelés) a következők előírások vonatkoztak, illetve vonatkoznak napjainkban.

A MOHOSZ által a Tisza-tóra kiadott 2007. évi horgászrend (I3.) rögzíti, hogy a Hortobágyi Nemzeti Park látogatható részein is tilos a sátorozás, a kempingezés, a tüzgyújtás és a növényzetirtás. A halgazdálkodási jog mai gyakorlója, a Tisza-tavi Sporthorgász K. N. Kft. által kialakított horgászrend (I4.), illetve a horgászjegyek mellékleteként elérheto” „információs füzet” (I5.) a hulladékgyüjtéssel, a szemetes helyen történő horgászat következményeivel részletesen foglalkozik, azonban nem tér ki a sátrazásra. Ugyanakkor a szervezet honlapján a „természetvédelmi előírások” már felhívják a figyelmet arra, hogy a „Hortobágyi Nemzeti Parkhoz tartozó területeken kerüljék a sátorozást, kempingezést, tűzgyújtást”.

A túrázók, vízitúrázók számára a védett területeken kívül általában az úgynevezett erdőtörvény (2009/ XXXVII) az iránymutató, mely szerint a 24 órát nem meghaladó sátrazáshoz nem kell az erdőgazdálkodó hozzájárulása, illetve partéltől számított 50 m-en belül a parti kezelő engedélyével lehet egy éjszakára sátrat verni. Azonban a Tisza-tavi kódex szerint (KÖTIVIZIG, 2010) a Tisza-tó azon részein, amelyek nem esnek természetvédelmi oltalom alá, sátorozni csak az erre a célra kijelölt állandó és ideiglenes helyen lehet. (A kódex alapján az időjárás elleni védelem céljából - hangsúlyozottan, csak a horgászat időtartamára - ideiglenesen kifeszített sátor, fólia stb. nem minősül sátrazásnak.) A kódex tartalmazza a hatóságok és érintett kezelők által együttesen kijelölt (legális, engedélyezett) sátorhelyeket. Mivel a „Tisza-tó mentén már kellő számban és közelségben található valamilyen szinten kiépített sátorozó hely, így az ezen kívül eső területeken a területkezelők nem járulnak hozzá a sátorozáshoz" (KÖTIVIZIG, 2010).

A horgászok igényeinek és a területre vonatkozó előírásoknak a figyelembevételével sejthető, hogy a Tisza-tónál az illegális táborozás (és az evvel gyakran együtt járó szemetelés) a mai napig létező probléma (I2). Probléma, nemcsak az elöírások megszegése, hanem a környezetre gyakorolt káros hatásai miatt is. Ezért fontosnak tartottuk megvizsgálni, hogy a tározó térségében milyen arányú a vadkempingezés jelenléte. A kutatásunk emellett az elmúlt 20 év változásait is segít kimutatni egy, a Debreceni Egyetem Tájvédelmi és Környezetföldrajzi Tanszékén 2000-ben elvégzett felmérésnek köszönhetően (Mokánszky, Hij, 2001).

Habár a vadkempingezés, tehát a kiépitett táborhelyeken kivül történó sátorverés bizonyos keretek között hazánkban is lehetséges, a vizsgált területre vonatkozó előírások miatt a publikáció további részében az illegális sátrazás szinonimájaként fogjuk használni! 


\section{Anyag és módszer}

A terepi adatgyüjtés során (a Tiszavalki-medencét kivéve) a tározó vízpartjait jártuk végig 2019 július-augusztus folyamán, miközben a horgászhelyek jellemzőit adatlapon rögzítettük és fotókat készíttetünk. A szárazföldről nem megközelíthető területeket csónakkal vizsgáltuk meg.

$\mathrm{Az}$ adatlapra a következő paramétereket jegyeztük fel:

- koordináták,

- vadkempingezéssel érintett terület kiterjedése $(\mathrm{m} 2)$,

- szemét jellege (van-e szemétgyüjtő, ez saját vagy halászati hasznosítótól vásárolt, mekkora a szétszórt szemét mennyisége),

- tűzrakóhely jellege (időszakos vagy állandó, ha állandó: anyaga, fedettsége),

- felépítmény jellege (mobil sátor, fix sátor, fa vagy lemez ház, többféle),

- mellékhelység jellege,

- egyéb elemek.

A felmért adatok elemzése és az illusztrációk egy részének elkészítése Excel és SPSS program segítségével történt. A térképek készítéséhez az Openstreetmap és a Google Earth adatait is segítségül hívva, a QGIS programot használtuk.

\section{Eredmények}

A terepbejárás során 44 ponton találtunk vadkempingezésre utaló jeleket. Ezen helyszínek megoszlása: Abádszalóki-medence 50\%, Sarudi-medence 48\%, Poroszlói-medence 2\%. Összevetve a 2000 folyamán végzett felmérés eredményeivel (Mokánszky-Hij, 2001), határozott csökkenés tapasztalható, ami a Hortobágyi Nemzeti Park részét jelentő Poroszlói-medencében a legnagyobb mértékű (1. ábra). A csökkenés emellett összefüggésbe hozható az infrastruktúra változásával is, ugyanis néhány, korábban vadkempingezéssel érintett területen ma már kikötő található (Abádszalóki-öböl). 


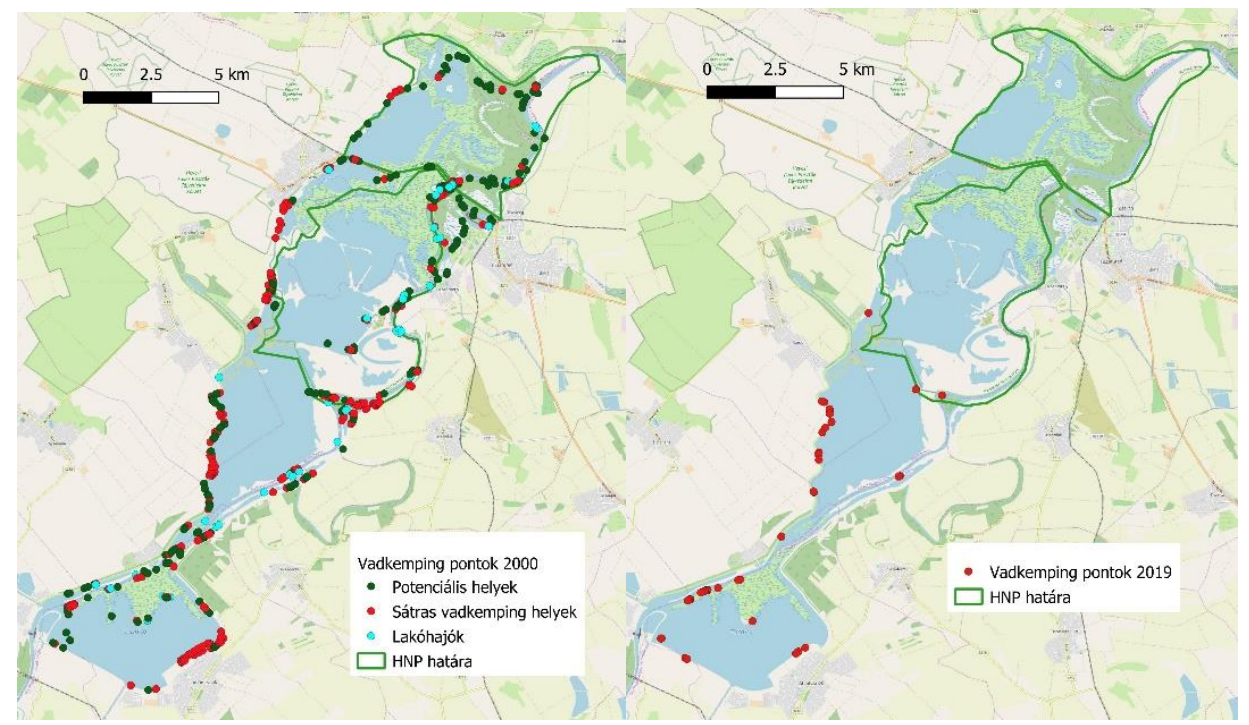

\section{1. ábra: Vadkempingezéssel érintett helyszínek a 2000 és 2019 során végzett felmérésben \\ Forrás: Mokánszky-Hij, 2001 (2000) és saját felmérés (2019) alapján}

A vadkempingre utaló nyomok vagy nyilvánvaló jelek esetén megfigyelhető, hogy nem a települések közvetlen közelében táboroznak le a horgászok, de többségében nem is mennek (a legközelebbi település belterületének határától számítva) négy kmnél messzebbre (2. ábra).

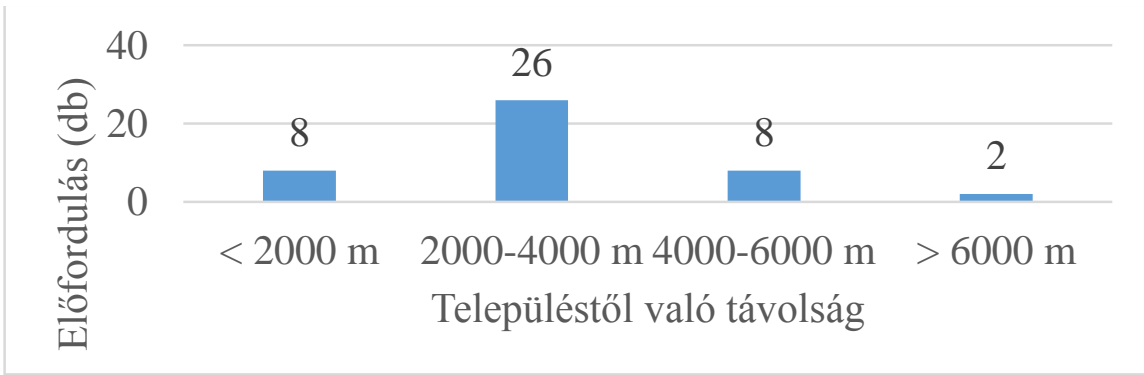

2. ábra: A vadkempingek legközelebbi településtől való távolsága 2019-ben

A vadkempingezés módja változatos, de többségében jóval meghaladja az „időjárás elleni védelem céljából kifeszített fólia" kategóriáját. A felmért pontokon öt kategóriát különítettünk el, melyek közül a mobil sátor a leggyakoribb (64\%). Azonban a hosszabb távú (akár több hónapig tartó) tartózkodásra utaló fix sátrakon (18\%) túl fa- vagy lemezház (3. ábra), illetve többféle megoldás kombinációja is előfordult (9\%). Lakóhajót, illetve lakókocsit szintén a helyszínek 9\%-án találtunk. 
Az időjárás elleni felépítmények mellett a hosszabb vízparti tartózkodásra utaló egyéb jelek is láthatóak a horgászhelyeken: a mobil napelemtől kezdve a sárdagasztást megakadályozó pallókon át a körbekerített paradicsom-ültetvényekig sajnos sok minden.

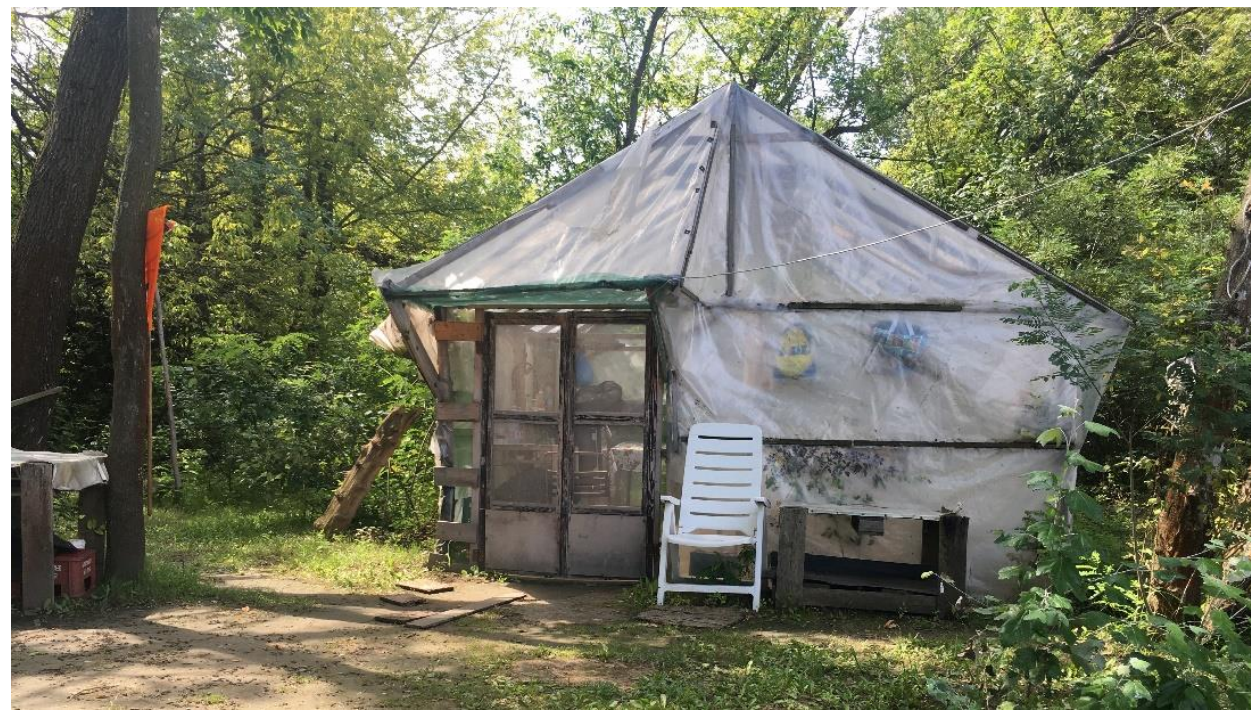

\section{3. ábra: Második otthon a tóparton?}

Forrás: Czicze G.

A különböző felépítmények azonban a településektől való távolság függvényében változnak. A településektől 2000-4000 m-re többféle felépítménnyel találkoztunk, míg ennél közelebb, illetve távolabb szinte csak mobil, hamar összeszerelhető sátrak fordultak elő (4. ábra).

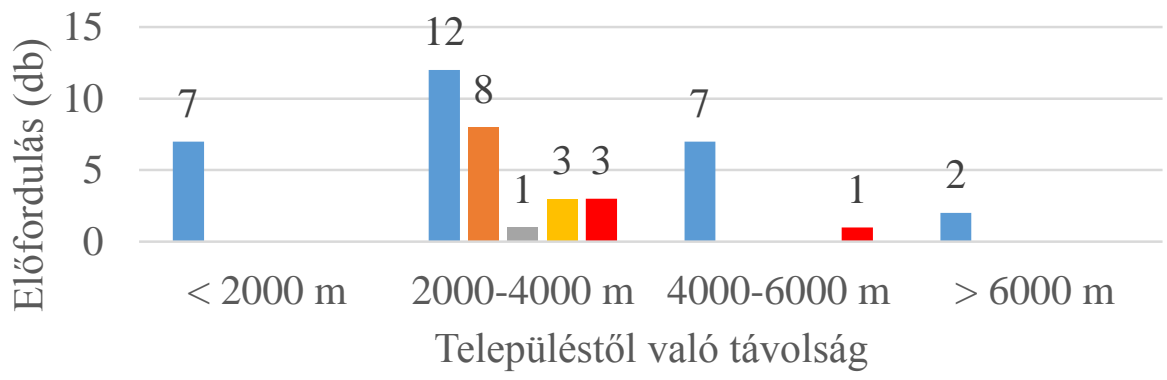

mobil sátor $\square$ fix sátor $\square$ fa vagy lemez ház $\square$ többféle $\square$ egyéb

\section{4. ábra: A felépítmények jellege a településektől való távolsággal változik}


Ahogy az 5. ábrán látható, a masszívabb felépítmények a legközelebbi közúttól legfeljebb (légvonalban) 500 m-re találhatóak.

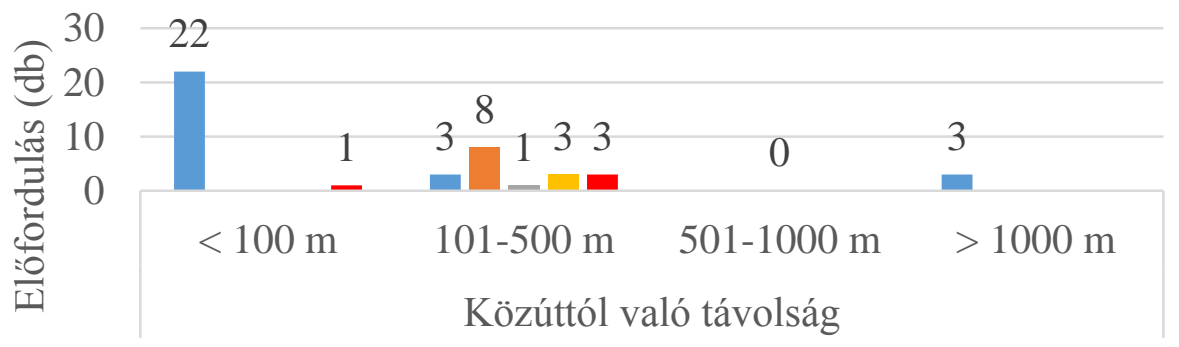

\section{mobil sátor $\square$ fix sátor $\square$ fa vagy lemez ház $\square$ többféle $\square$ egyéb}

\section{5. ábra: A közúttól való (légvonalban mért) távolság meghatározó}

A hosszabb tartózkodás általában nagyobb hulladéktermeléssel is jár. A horgászrend 18. pontja szerint „A szemetes helyen horgászó személytöl a területi jegy bevonásra kerül. A horgász köteles a horgászhelyet tisztán hátra hagyni. "Ha ehhez a terület kezelője által biztosított (megvásárolható) sárga zsákot használja valaki, azt a cég el is szállítja. Ennek ellenére a többség nem él evvel a lehetőséggel, saját zsákba gyűjtik a szemetet, és a helyszínek 61\%-ában előfordult szétszórt hulladék is. A legközelebbi közúttól légvonalban mért 500 m-en belül volt a legtöbb szemét (sok esetben a tüzrakóhelybe dobálva, még a műanyag csontkukacos doboz is).

\section{Konklúzió}

Habár a vadkempingezés jelenléte a Tisza-tónál csökkent, de napjainkban is fennálló probléma. A csökkenést egyrészt a szigorúbb ellenőrzés eredményezte, emellett hozzájárult az infrastruktúra változása is.

A továbbra is fennálló tájképi és környezeti terhelést a masszívabb felépítmények, a komfortnövelő beavatkozások és a hulladékkezelés jelentik, melyek legfőképpen a településektől 2000-4000 méterre találhatóak, a legközelebbi közúttól (légvonalban) viszont csak alig 500 méterre.

A terület kezelőjének hatékonyabb menedzsmentintézkedését véleményünk szerint a tájékoztatás és a szabályok betartatása, a gyakoribb ellenőrzés segítené. 


\section{Hivatkozott források}

[1.] Benkhard B. - Vasvári M. - Molnárné B. R. K. (2013): A horgászturizmus gazdasági hatása a Tisza-tó térségében. [Kézirat].

[2.] Dávid L. - Kóródi M. - Puczkó L. - Vasvári M. (2010): A Tisza-tó imázsa és márkázottsága. Turizmus Bulletin, 14. évf. 1-2. sz. 85-92. o.

[3.] Halasi-Kovács B. - Harka Á. (2000): Pályázat a Tisza-tó halászati hasznosítására. [Kézirat]. 46 o.

[4.] Harka Á. (1985): A Kiskörei víztározó halállománya. Halászat, 78. sz. 3537. o.

[5.] [KÖTIVIZIG (2010): Tisza-tavi kódex. Forrás:

[6.] http://www.kotivizig.hu/doksik/tisza_tavi_kodex/tiszatavikodex.pdf

[7.] KSH (2013): Jelentés a turizmus 2012. évi teljesítményéről.

[8.] KSH (2018): Helyzetkép a turizmus, vendéglátás ágazatról.

[9.] Mészáros, J. (1974): Közép-Tisza-vidéki Intéz Bizottság alakult. Jászkunság. 20. évf. 2. sz., 66-71. o.

[10.] Mokánszki A. - Hij Z. (2001): A turizmus megjelenése és hatásai a Tiszatónál. [Diplomamunka]. Debrecen. 79 o.

[I1] http://web.okir.hu/map/?config=TIR\&lang=hu

[I2] http://turizmusonline.hu/aktualis/cikk/valtozas_a_tisza_tavi_horgaszengedelyekben

[I3] http://www.aranymedve.hu/horgaszat.htm

[14] http://sporthorgasz.eu/horgaszrend

[I5] http://sporthorgasz.eu/wp-content/uploads/2020/01/informacios_fuzet_2020.pdf

\section{Szerzők:}

Czicze Gábor

Földrajz BSc

III. évfolyam

cgaboka@gmail.com

\section{Dr. Benkhard Borbála Rita}

tanársegéd

Debreceni Egyetem, Tájvédelmi és Környezetföldrajzi Tanszék

benkhard.borbala@science.unideb.hu 